\title{
Stigmatising Others through Neighborhood Talk in Indonesia
}

\section{Zane Goebel, La Trobe University}

Drawing on sociology, anthropology, semiotics, and literary studies among others (Bakhtin 1981; Bourdieu 1991; Foucault 1978; Goffman 1967; Hymes 1974; Peirce 1931-1958; Sacks 1986 [1972]), contemporary linguistic anthropology has approached the idea of stigma and closely related ideas, such as racism, difference and othering, from small-scale to large-scale perspectives. What I mean by small-scale perspective is that data is typically obtained from small, sometimes isolated settings, where face-toface talk involving two or more people is a common focus. A large-scale perspective typically includes a view of multiple sites and a reliance on data that is produced in 'one-to-many participation frameworks,' for example, teacher to pupils in school and presenters to radio and television audiences.

A focus on the language practices of minorities in small-scale settings has helped us understand how language practices become stigmatised while contributing to a vicious circle of social disadvantage for these minorities (Philips 1983). Some linguistic anthropologists have focused on large-scale perspectives by seeking to understand how particular ideologies about language and their speakers are formed and recirculated over long-time scales and in large-scale settings to produce stereotypes (Errington 2000, 2001; Inoue 2006) or the types of discourses discussed and critiqued by Foucault (1978). Others have shown how the two different scales are inter-related (Errington 1998; Wortham 2006), thus revealing how linguistic forms and social practices that are associated with widely circulating stereotypes are reused or 'recontextualised' (Bauman

PORTAL Journal of Multidisciplinary International Studies, vol. 11, no. 1, January 2014.

Stigma and Exclusion in Cross-Cultural Contexts Special Issue, guest edited by Annie Pohlman, Sol Rojas-Lizana and Maryam Jamarani. 
\& Briggs 1990) to perform a particular identity or to identify others in everyday face-toface talk.

Common to these studies are the ideas that stigmatisation and stereotyping are unfinished and emergent processes that occur on different but inter-related scales; hence the use of '-isation' and '-ing.' The inter-related nature of these different scales means that what happens in one scale-for example face-to-face talk-draws upon and contributes to processes on another scale. Thus, while stigma and stereotype are terms that point to similar semiotic outcomes, namely the linking of negative characteristics to a persona and the recontextualisation of that social type along with associated signs in new contexts, here I reserve the term stereotype to refer to a more stable model of personhood that is an outcome of large-scale processes. I use stigmatisation to refer to the process of evaluating someone as different to local exemplars of moral behaviour. Over interactional time, in a small-scale setting individual instances of stigmatisation contribute to the construction of an emergent local model of personhood. People involved in this process (face-to-face talk) draw upon and use signs from more widely known stereotypes to stigmatise others while positioning themselves as moral exemplars.

In this article I use this take on micro-macro relationships to focus on a series of monthly neighbourhood meetings that I recorded in Semarang, Indonesia, as part of fieldwork I carried out from April 1996 until July 1998. In looking at the talk in these meetings, I was especially concerned with how one non-present neighbour is stigmatised over time and how this process draws upon widely circulating negative stereotypes about Indonesians of Chinese ancestry. As I move through my analysis it becomes clear that in this setting it is hard to assign responsibility for stigmatisation to any person in particular. This is because stigmatisation emerges through numerous, often implicit, conversational contributions that point to or 'index' Chineseness, but that rarely explicitly say that someone is Chinese.

\section{Stereotypes, stigma, and talk}

One-to-many participation frameworks have been implicated in the process of positive and negative stereotype formation. Those who represent the 'one' (teachers, experts of one type or another, academics, celebrities, and so on) in one-to-many participation 
frameworks typically model and normalise particular ways of speaking and ways of perceiving others (Agha 2007). These models are authorised because of their association with expertise and/or institutions that have the political means to regiment those frameworks. I regard this as institutionally authorised one-to-many participation frameworks. Yet, as Agha’s (2007) work reminds us, while teachers, experts and celebrities may act as models of ways of speaking and interacting, much of the semiotic content in classrooms, television shows and so on enables audiences to recognise semiotic features of this content, rather than to reproduce this content. In cases where semiotic features are drawn upon or emulated in other contexts—face-to-face talktypically it is imperfect copies of these features.

One outcome of cases where these semiotic fragments are reused in multiple settings (classrooms, television programs, and government documents) is widely held beliefs about languages and their users (that is, language ideologies). Repetition in multiple settings not only increases the possibility of recognition by a wide segment of society, but it can also modify or reinforce earlier understandings about semiotic features or signs and their relationship to people. This intersection of signs and types of people form stereotypes along with what Agha (2007) refers to as 'semiotic registers.' Semiotic registers can be defined as a constellation of signs whereby the use of one sign associated with this register points to other signs along with the types of people associated with these signs. In this sense, signs are recognised as emblems of identity. Multiple semiotic registers circulate in any population and people are only familiar with and able to use some of these. This ability to recognise emblems that index particular identities also enables a speaker to categorise their interlocutor as similar or different to the speaker (Irvine 2001). In conversational storytelling and gossip difference at some level can be reconstructed as a stigmatised or out-group identity.

Approaches to conversational storytelling and gossip are especially suited as a framework for examining and understanding processes associated with the stigmatisation of others, because these genres are made up of and often begin with acts of categorisation or social identification that are grounded in the recognition of sameness and difference (Besnier 2009; Georgakopoulou 2007). A common finding of work on storytelling and gossip is that both these genres often relate back to an event that occurred in a way that the teller(s) did not expect (Bauman 2004; Besnier 2009; 
Georgakopoulou 2007; Labov \& Waletzky 1967; Ochs \& Capps 2001). This breach of expectations then generates a telling about the event and the persons involved, which functions to either help the teller and listeners to understand why the event occurred, while often positioning the teller as an exemplar of local moral codes. In contrast, the person who broke these expectations is positioned as immoral or deviant, that is, they are stigmatised.

Audiences are key to the success of both storytelling and gossip. Indeed, both genres require an audience to side with the teller. Typically, getting on side means agreeing with or ratifying what the teller says, while also making contributions to the story or gossip in a way that further stigmatises the antagonist. One of the outcomes of the joint production of stories and gossip is that it is also often hard to assign responsibility for what is said to any person in particular (Besnier 2009). Stories and gossip are typically consequential for the life of the antagonist. In the case of stories, antagonists may be stigmatised (Ochs \& Capps 2001), while in the worst cases of gossip antagonists can be physically harmed (Besnier 2009; Stewart \& Strathern 2004). A typical outcome of both these genres is the reproduction of local norms for interactional behaviour and the change in the behaviour of those being gossiped about (Besnier 2009; Goebel 2010; Stewart \& Strathern 2004).

\section{Stereotypes of Chineseness in Indonesia}

Since Dutch colonial times institutionally authorised one-to-many participation frameworks have figured heavily in the formation of stereotypes about Indonesians of Chinese ancestry (hereafter Chinese), to the extent that someone who engages in certain social practices is socially identified as Chinese. For example, historical work on the Dutch colonial period between 1860 to 1930 points to an important period in the formation of links between the activities of trade and commerce, schooling and religious practices, political affiliation, social space, and language to form models or stereotypes of Chineseness (Coppel 1983).

During the period between 1945-1967 many of the signs that could be read as indicative of Chineseness persisted-such as, engagement in trading and commerce, economic advantage, space, political affiliation, language, social class, exclusive schooling, and religion —while new signs became associated with this category of personhood. In particular, increasingly common discourses found in networks of anti-communist and 
anti-foreigner/Chinese organisations (including their newspapers and magazines) helped cement the association of Chineseness with communism and opportunism (Coppel 1983). Just as importantly, their perceived position as economic exploiters of Indonesia became entrenched as did their relationships with military personnel. This was in part due to discriminatory hiring practices in successive governments — which left trade and commerce as the only viable means that Chinese could earning a living-and because they had to pay those in power for protection (Coppel 1983). During August 1966 the use of cina to refer to Chinese living in Indonesia also became authorised by an anticommunist military faction of the government when it passed a resolution that Chinese should be referred to as orang Cina, despite the term being seen as derogatory by many Indonesians (Coppel 1983: 89).

During the New Order period of government under General Suharto (1967-1998) many negative signs associated with Chineseness persisted. For example, perceptions of their dominance of the Indonesian economy continued as did perceptions of their symbiotic relationship with those in powerful positions (Coppel 1983; Purdey 2006). This was in part due to the Suharto government's increasing reliance on particular Chinese to help them jointly form large domestic corporations, which were guaranteed markets under a regime of tariffs (Purdey 2006; Vickers 2005). These perceptions were also a result of the continued need of Chinese to seek protection of family, person and property from mass violence that had occurred in the period between 1945 to 1966 (Coppel 1983).

The wavering of Indonesia's economic and political stability in the early 1990s, coupled with the rapid expansion of Indonesia's television network (Kitley 2000), had an impact on the circulation of negative stereotypes of Chineseness. The prior twenty years of sustained growth in GDP had fostered the emergence of middle-class students who began to seek a cleaner and transparent government free of corruption and collusion (Vickers 2005). Some of the main targets of criticism were Chinese (Purdey 2006). These criticisms about societal inequality were aided by country-wide telecasts in 1990 and 1995 where some of the wealthiest Chinese from large companies were asked by President Suharto to give substantial amounts of money to co-operatives and to the poor (Chua 2004; Purdey 2006). This occurred in a context where the Indonesian development program had produced increasing disparities between the rich and the poor (Chua 2004; Purdey 2006). 
It is also important to note that at the time of the broadcasts most forms of media were still strictly censored with the result that only government approved news became news (Sen \& Hill 2000). Thus, for those who had access to televisions at this time, they had no access to other forms of information that may have provided alternate, less negative associations with Chineseness. In linking these representations with their uptake, Purdey (2006) points out that after the 1995 televised event a number of occurrences of mass violence in Java were directed towards signs associated with Chineseness. Such emblems of Chineseness included shops, shopping malls, churches, Buddhist shrines, houses and property in areas perceived to have high numbers of Indonesian-Chinese.

Those seeking political mileage from this violence often blamed the victim by linking the violence with perceptions about social inequality, opulent lifestyles, selfishness, Christianisation in Islamic areas, and corrupt relations between Indonesian-Chinese and members of the military and government (Purdey 2006). In this sense, the last years of the New Order regime can also be characterised by an increase in the circulation of state-authorised negative stereotypes of Chineseness. Indeed, Purdey’s analysis highlights that during the time of my own fieldwork, which I will report on below, Chineseness continued to be associated with signs of deviance. Below I demonstrate how these widely circulating signs associated with various stereotypes of Chineseness are appropriated in everyday talk to stigmatise a particular person during two male ward meetings that occurred in December 1996 and January 1997.

\section{Fieldwork in Semarang, Indonesia}

The data that I present here was gathered during two-and-a-half years of fieldwork in two wards (Rukun Tetangga) in Semarang between April 1996 and July 1998. Here I focus on Ward 8, which is where I and my family lived. This middle-income ward was primarily populated by tertiary educated middle echelon public servants and was part of a government housing estate established in 1988 and designed for low- to middleincome public servants. Within this ward there were a high number of unoccupied houses. As we will see, this had a negative impact on ward social life and talk, culminating in the stigmatisation of one ward member. In particular, this ward member was conversationally constructed as deviant and similar to widely circulating stereotypes of Chineseness. 
Many of my recordings were transcribed with the help of Indonesian research assistants, some of whom were also members of this ward. Part of the transcription process involved classification of linguistic forms and interpreting the meaning of moving between Indonesian and Javanese (codeswitching), which was common in everyday talk. While codeswitching and the way one speaks is an important aspect of meaning-making in these interactions, to keep this paper succinct I will not focus on movement between Javanese and Indonesian. ${ }^{1}$ I will, however, sketch out the intersection of a number of local social practices and local categories of personhood that emerged as part of ward level concerns that circulated prior to two monthly meetings that I look at shortly.

In the months leading up to the December 1996 and January 1997 ward meetings the tranquility of what was otherwise viewed as a safe and desirable place to reside was threatened. For example, a number of robberies and unwanted intrusions into ward members' houses occurred during this period. The upcoming presidential election also promised marauding supporters, who on occasion created problems in local wards. These concerns made their way into discussions in the December meeting along with more general talk about youth crime and drug usage, anxieties about the social unrest that would come with the upcoming elections, and how to ensure that the security guard could be relied upon to do his job. The January meeting was held during the Islamic fasting month of Ramadan, when messages of giving to the poor and less fortunate were common in newspapers, television serials, soap operas, and in sermons given at the mosque in the evenings and at Friday prayers. The sermons were always delivered over a loudspeaker enabling most of those living in the neighbourhood to hear them. During Ramadan the cost of living also increased, further pressuring family budgets. In addition, at the end of Ramadan the ward held a celebration that also required monetary contributions from each family.

For the families of Ward 8, such financial pressures were exacerbated by the need to pay for the recent construction of a guard post and for a full-time security guard to attend the post in the evenings. Other infrastructure improvements became necessary during this time, including the surfacing of the unsealed road at the northern end of the ward, which was in desperate need of repair due to the damage caused by an increasingly large amount of traffic and heavy rains during the wet season. The rains

\footnotetext{
${ }^{1}$ For those interested in this aspect of interactional practice please see Goebel (2010, Chapters 4, 7 and 8).
} 
also caused regular minor flooding in this and adjoining wards because the drainage was regularly blocked with silt and garbage. This, together with the increasing occurrence of serious water-born mosquito diseases, such as dengue fever, meant the drains needed to be cleaned. Again, this required further financial contributions by ward members. All of these local circumstances relating to the financial needs of the ward came at a time when only about half of the twenty-three families in this ward attended ward meetings and made financial contributions towards such costs. Indeed, ward finances could not even cover one infrastructure project, as we will hear from a number of the ward members. In what follows we take a closer look at how discussions at a series of meetings were shadowed by these local circumstances and entangled with widely circulating negative stereotypes about Chineseness.

\section{The December meeting: The start of stigmatisation}

In this section I focus on discussions during a routine male ward meeting that occurred in December 1996. Part of the function of these meetings was to help disseminate state development policy—which among other things included ideas and directives on ward development — and for members to plan for and collect finances to carry out such directives and their own initiatives. Another function, which was often pointed out at the official opening of these meetings, was to provide an opportunity to nyumbang rasa 'to share one's feelings,' which is intimately tied to the other functions of these meetings. Like most ward meetings, the meeting took place in the front room of the host's house, Tri (all names are pseudonyms). Although attendance by all ward members was seen by members as ideal, this never occurred and attendance fluctuated between nine and thirteen male heads of household. Indeed, of the eleven members who attended this meeting, those who attended earlier meetings without fail only included Taufik, Pujianto, Abdurrahman, Marwito, Joko, Naryono and myself. Dono, Giono and three other members not present at this meeting (Sumaryono, Feizel and Matius) attended the meetings every few months. Kris and Tri had not attended a meeting since I began attending in April 1996. As we will see below, non-attendance was quite a common topic at this and the next meeting and it is an important factor in the stigmatisation of one ward member, Kris. I should point out that stigmatisation was not a direct outcome of one conversation; nor for the most part did it appear as an intended outcome of any individuals' talk. Stigmatisation has multiple potential trajectories and responsibility for stigmatisation does not lie with any individual in particular. 
During the first ten minutes of the two hour meeting interaction among participants related to the collecting of monthly dues and talking about the new guard post. Kris is not present but is talked about by Joko as the major creditor to the ward. This is so because most of the material for the guard post was purchased from the hardware store owned and operated by Kris. The meeting is then officially started by the head of the ward, Sunaryono, who lists agenda items before briefly postponing discussion to note that a new resident, Roi, wants permission for large trucks to regularly pick-up and deliver merchandise. ${ }^{2}$ Sunaryono asks for input about this matter because of the damage that heavy trucks will do to the ward road.

Reiterating immediately preceding ‘private’ talk by Tri, Dono and Joko, Pujianto publicly suggests that they should only allow Roi to use small domestic-sized vehicles for transporting merchandise because of the damage large trucks may cause and the subsequent financial burden on the ward. (Here Pujianto raises his voice, which causes the subsequent silence of other members.) In the discussion immediately preceding Extract 1, Tri officially seconds this idea. He does this through the recounting of a story about his experience with a neighbour from another ward after Tri erected a metal pole (portal) in the middle of the road. This discussion represents the start of a much longer sequence of conversation that stigmatises the absent Kris. ${ }^{3}$

Extract 1: The joint identification of a trader

Tri

1

3

4

Joko

$5 \quad$ Pak Kris.

Pujianto

6

Tri

$7 \quad$ Kris udah lama nggak apa apa. Pujianto

8 itu, namanya?

Kris. Iya.
Ah maka, ternyata, ini sudah mengurangi hal hal yang beban berat. Memang dari sana, mulai, tempatnya Pak RT itu, seperti Pak Dagang itu, sapa
But what happened was that the pole stopped heavy [trucks] using this street. Indeed, from the head of the ward's house (referred to as Mr. Ward) and like Mr. Trader, what is his name?

Mr. Kris.

Kris.

It's already been some time and Kris has no problems [with it].

Yes.

\footnotetext{
${ }^{2}$ The names Roi and Kris are often associated with Christianity, which is also associated with widely circulating stereotypes of Chineseness in Indonesia.

${ }^{3}$ My transcription conventions follow written punctuation by using a comma to indicate where the participants pause and a period where they finish a sentence. Brackets with groups of three question marks '(???)' indicate unclear words.
} 
Here talking about local issues relating to road usage helps begin a process of stigmatisation through the positioning of the non-present Kris as a 'trader' on lines 3-6. This talk is also important for two other reasons. First, we can see here that Tri's name search on lines 3-4 helps to involve other participants who provide the name and then repeat it (lines 5-7). Similar in many ways to the outcome of 'information holding' described by Besnier (2009), this makes it hard to assign responsibility for naming Kris as a trader to any one of the three participants. In this sense, we can see that the identification of Kris as a trader is joint work.

Second, although 'trader' as type of person or social type could equally be read as involving Indonesians who are not of Chinese-ancestry, with recourse to enduring stereotypes some might also interpret 'trader' as ‘someone of Chinese-ancestry.' In this sense, we are seeing these stereotypes becoming potentially entwined in local talk. Even so, some of those present may have known about Kris's Chinese-ancestry, especially the ward head and secretary due to their access to the personal information that each resident must provide to ward administrators. In this sense, although Chineseness as one aspect of Kris's identity may be known to participants, it is left ambiguous in the talk. However, such a reading becomes increasingly possible as 'trader' continues to be used and modified in subsequent talk during this meeting. Indeed, in the next transcript, which follows soon after the talk in Extract 1, we see Tri's talk helping to add further characteristics to 'traders' in general. The interim talk, mostly by Tri, relates to how the responsibility for the housing estate where they live has now been handed over to the local government, which means that it is the ward residents' responsibility to pay for the upgrading and maintenance of the roads in its immediate area.

\section{Extract 2: Linking traders with deviance}

$\begin{array}{ll}\text { Tri } & \\ 1 & \text { Makanya, nanti pak, secara tegas saja. Saya di } \\ 2 & \text { belakang Pak RT lah saya nanti (??? ). Saya sudah } \\ 3 & \text { matur pak lurah itu, dan pak lurah nyetujui dia. } \\ 4 & \text { Hanya karena kan kadang kadang, pengaturan itu } \\ 5 & \text { kan. 'Yo ra ngerti lah,' nek wong dagang itu kan } \\ 6 & \text { nganu ngga ngerti yang jelas. Pengaturan itu mereka } \\ 7 & \text { ngga bisa tegas, karena, kurang jujur bisa masuk. } \\ & \\ \text { Dono } & \\ 8 & \text { Iya. }\end{array}$

So later we have to be firm, I'm right behind the head of the ward (???). I've already asked the subdistrict head, the sub-district head agreed but he only, right, sometimes because rules 'yeah [I] don't understood,' if it is a trader right? Um [they] don't understand clearly these sorts of rules right, the subdistrict finds it hard to be firm because sometimes they are not entirely honest and enter [the ward].

Yes. 
In the above conversation, Tri builds upon Sunaryono’s earlier identification of Roi (also as a trader) by noting a need to be quite blunt in their dealings with such persons because traders tend not to understand rules and can be dishonest (lines 5-7). Dono appears to agree with this characterisation at line 8 and in an extended response shortly after the talk represented in Extract 2. In doing so, we begin to see a local linking of a deviant aspect with 'trader,' though neither Roi nor Kris are explicitly talked about in these terms. As with the previous extract we also see that this situated creation of a deviant social type is a joint activity.

Tri and Dono continue to jointly build upon the previous identity category of deviant trader by more directly associating it with a named person. In this case, Roi is now imagined to be someone who might oppose the ward's decision and bring along some support. In doing so, Roi’s identity becomes entwined with more enduring stereotypes, especially the cukong relationship where Chinese business people pay protection money to government officials, such as military and police personnel. As the talk progresses we find that Tri, Dono and Adi note that Roi's trucks have actually already begun to arrive late at night, despite no official permission being given. In doing so, this establishes relationships with earlier talk, especially traders who do not follow rules (Extract 2).

After noting that the ward has already been quite generous in their dealings with traders, Tri jovially notes that one example of this lenience was with Kris. This talk (not reproduced here) more directly positions Kris as deviant. As with Roi, such deviance is also now directly linked with another named person, Kris. The construction of this deviance is again a joint effort, this time on the part of Tri and Giono. The breaching of expectations and the involvement of an audience in further evaluating the actions of Kris also becomes entwined with enduring stereotypes relating to Chineseness, especially those associated with selfishness and making money. At this stage, however, we cannot be sure that such links are being unambiguously invoked in this talk. We need to follow the talk to see whether, to what extent and how such associations solidify.

About thirty minutes later-after talk about the ward guard who rarely does his job, recent break-ins, drunken youth and general ward insecurity - the topic turns to payments toward the guard post. At this stage Kris is again mentioned as the person from whom the ward has bought all the material for the guard post, resulting in a debt of 700,000 rupiah. We also hear that there are many absentee landlords who have not paid 
their obligatory 40,000 rupiah toward the guard post. In doing so, the local categories of payer and non-payer of ward dues are constructed. After Joko recounts the sorry state of ward finances in regard to paying for the new guard post, these categories soon become linked with another pair of local categories_-namely, donators and non-donators-as Tri says he will donate an extra 100,000 rupiah. He adds to this by suggesting that Kris should donate more as others jokingly suggest that if anyone else would like to donate further, then they should not hesitate. Shortly thereafter, Abdurrahman and Pujianto ask how much Kris has actually donated. Extract 3 shows that while initially Kris is reported to have donated 100,000, it is established that he has only donated 10,000 rupiah (the same amount donated by non-home owners).

\section{Extract 3: Kris hasn't donated yet}

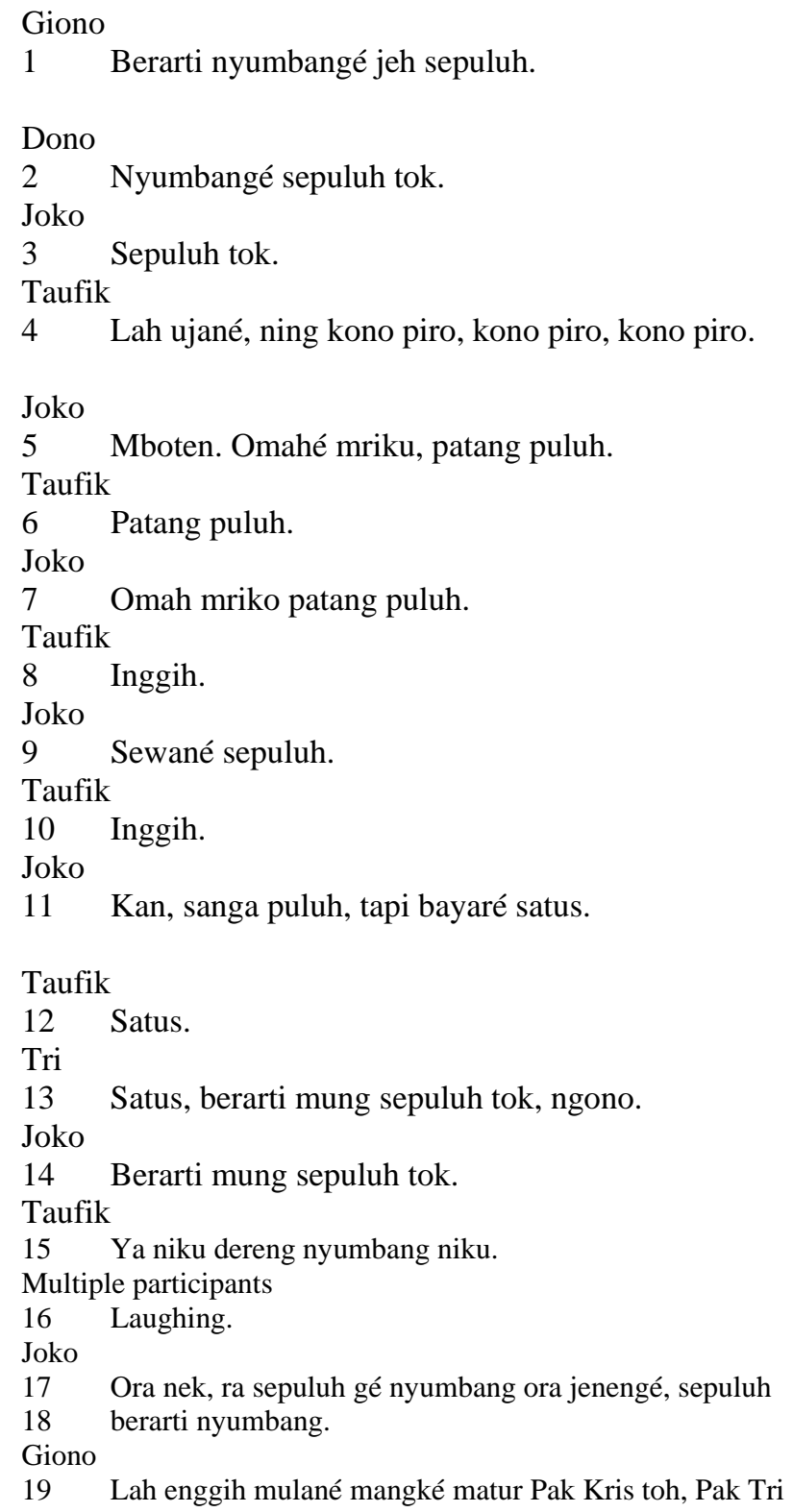

So that means he has only donated ten [thousand rupiah].

He has only donated ten.

Just ten.

For example, over there how much, over there how much, over there how much?

No. The house over there forty [thousand rupiah].

Forty.

The [other] house over there forty.

Yes.

The rented house, ten.

Right.

That is ninety [thousand rupiah] right. But he paid one hundred [thousand rupiah].

One hundred.

One hundred that means only ten.

That means just ten.

Yes that [means he] hasn’t yet donated.

Laughing.

No, if there wasn't the ten that was donated, that would be called not donating. [But] ten means he's donated.

Yes that is right. So later tell Mr. Kris, heh Mr. Tri Mr. 


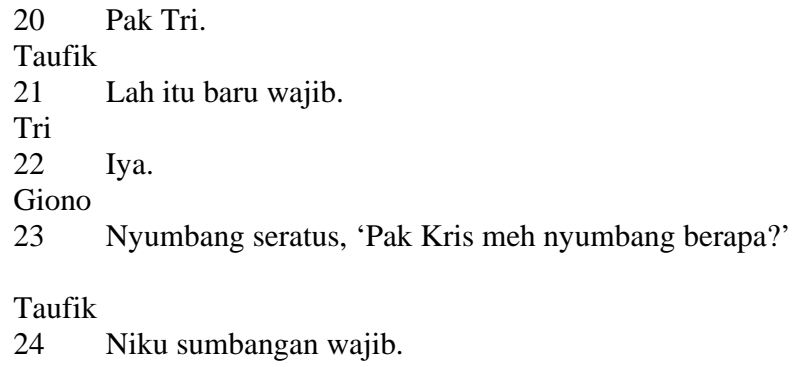

Tri.

Well that is just the normal obligation.

Yes.

Donated one hundred. 'Mr. Kris how much do you want to donate.'

That's the normal obligatory donation.

As we can see in lines 1-3 and 13-14 four participants-Giono, Dono, Tri and Jokoevaluate this donation using jeh (only), mung (just) or tok (only). When combined with other talk we can see the prior category of generous donator, Tri, solidifying alongside the not-so-generous donator, Kris. For example, Taufik’s comments about Kris’s contribution as 'not yet a donation' (line 15) but rather 'the normal obligatory donation' (lines 21 and 24) positions Kris as the not-so-generous donator. Another example of this type of positioning is Giono’s suggestion that they use Tri's donation as an example when talking to Kris (line 23). As with earlier talk about deviance, this positioning is jointly achieved and has involved seven of the eleven participants in this meeting (Abdurrahman, Pujianto, Tri, Dono, Taufik, Giono and Joko). In addition, while this type of stigmatisation seems to further entwine Kris's identity with more enduring stereotypes of Chinese as tight-fisted and with ideas about the wealthy giving to the less fortunate, at this stage such positioning appears ambiguous, as the conversation here is rather jovial with all participants joking and laughing about these suggestions.

During the following ten minutes, the talk moves back to other ward members who have not paid any monthly dues, their forty thousand toward the guard post, nor donated any money. In particular, discussion turns to how to obtain money from these sorts of people who also never attend meetings. Taufik and Joko go as far to say as the rich are the hardest to get contributions from, while naming a number of non-present ward members. Just as importantly, Joko tells everyone that Kris never misses a chance to collect money that the ward owes him. Together, all of this conversational activity helps further solidify local categories — such as generous donator, donator, payer of dues, and their opposites - in addition to attender and non-attender of meetings, debt-collecting trader (Kris), and rich and poor folk. At the end of the meeting Tri singles out Dono as the most consistently generous member of the ward. This also helps solidify the categories constructed during this meeting, while enduring stereotypes relating to Chineseness continue to invite readings of Kris's behaviours as stereotypically Chinese. 
In summarising the discussion thus far, the people who are positioning others as nonnormative or deviant in the ward context are inferring that they themselves are persons who do not fit the deviant category. As such we begin to see stigmatisation as an emergent process in the ward setting. What stands out here is that stigmatisation cannot be pinpointed to any particular piece of talk or person, as it is something that is jointly achieved by an increasingly large number of attendees over the course of a two hour meeting. It needs to be pointed out that in tandem with the stigmatisation processwhich constructs Kris as deviant social type-ideas about what is considered nondeviant or ideal in this ward are also reinforced. We have also seen how stereotypes of Chineseness potentially contribute to this local process of stigmatisation. In the next meeting, discussed below, similar conversations occurred at a time when the institutional authorisation of public anti-Chinese sentiment was becoming more common. This seemed to make the implied readings of Chineseness less ambiguous.

\section{The January 1997 meeting: From stigmatisation to threats of verbal abuse}

In this section I look at the routine meeting that occurred one month after the meeting discussed above. In particular, I focus on how Kris's identity as a stingy, non-attending trader and ward member continues to be invoked and built upon in the talk in this meeting. As noted earlier, this co-occurred with the ward's financial situation and the Islamic fasting month. In this meeting there are just nine participants, seven of whom were at the previous December meeting (Tri, Dono and Giono are not present). Kris is again absent despite being invited both orally and in writing. During the early part of this meeting non-attendance is linked to the ward's financial situation. We can thus see links with categories from the December meeting, especially those of attendee and nonattendee, and payer and non-payer of ward dues. We also see how these local categories relate to the ward's finances and the financial burden low attendance places on those who attend. All those present are reminded that the ward still owes Kris 250,000 rupiah for the material that was used for the building of the guard post.

While a number of ward members are named as non-contributors in the talk immediately preceding Extract 4, Kris becomes the focus of discussion through the recounting of his financial contribution toward the construction of the guard post and his ownership of three houses. Here we see other links to categories that emerged in the previous meeting, especially those relating to generosity-stinginess and wealthy- 
ordinary folk. This discussion involves Feizel (the ward treasurer), who was not present at the December meeting.

Extract 4: Kris as a non-attending, possibly stingy businessperson

Joko

1 Saur sauré kas niku? Kasé sing ora iso nyaur.

Feizel

$2 \quad$ Pak Kris ini, dia sekali sekali suruh hadirlah.

Joko

3 Sudah saya pesen ok.

Feizel

$4 \quad$ Ndak pernah hadir. Nanti saya ngomong supaya

5 nyumbang lagilah.

Joko

$6 \quad$ Sudah saya pesen.

Feizel

7 (???) sama sama, orang kita kita ini.

Joko

$8 \quad$ Nek jeh sore mau ditelpon telpon tu, 'nggak bisa.'

Feizel

$9 \quad$ Kan pengusaha itu.
Pay the debt, the debt from [ward] cash? The [ward] cash is not sufficient to pay the debt.

This Mr. Kris, he should be told to attend every once in a while.

Actually, I’ve already told him.

He has never been present. I'll talk to him so he donates some more.

I've already told him.

(???) same, the same as us here.

This afternoon, earlier [I] phoned him, [he said] 'I can't come.'

He is a business person, right!

Feizel's reference to Kris's non-attendance (lines 2 and 4), his need to donate again (lines 4-5) and his positioning as a businessperson (line 9) has links with prior talk in this meeting and talk in the December meeting. This talk also helps to further solidify categories of non-payers (the talk just prior to Extract 4), donators (line 5), business people or traders (line 9), and those who do and do not work for the common good of the ward (lines 2-5 and the talk just prior to this extract), while also linking them directly with named persons in the ward, in this case Kris.

At this stage of the conversation potential links are made between the ward's financial woes, Kris and businesspeople as a category of persons who should donate. During the fasting month 'give to the needy' was a ubiquitous message for all wealthy persons, and in a sense we are starting to see a conflation of widely circulating Islamic ideas about social relations (wealthy giving to the poor) with local circumstances (wealthy inhabitants whether Muslim or not making greater contributions than their poorer neighbours). As with earlier extracts, this positioning of Kris as someone who should donate more is a joint effort, in this case involving two participants. 
The positioning of Kris as someone who should donate more further solidifies in the talk represented in Extract 5. This talk immediately follows that represented in Extract 4.

Extract 5: Comparing behaviour: generosity and stinginess

Pujianto

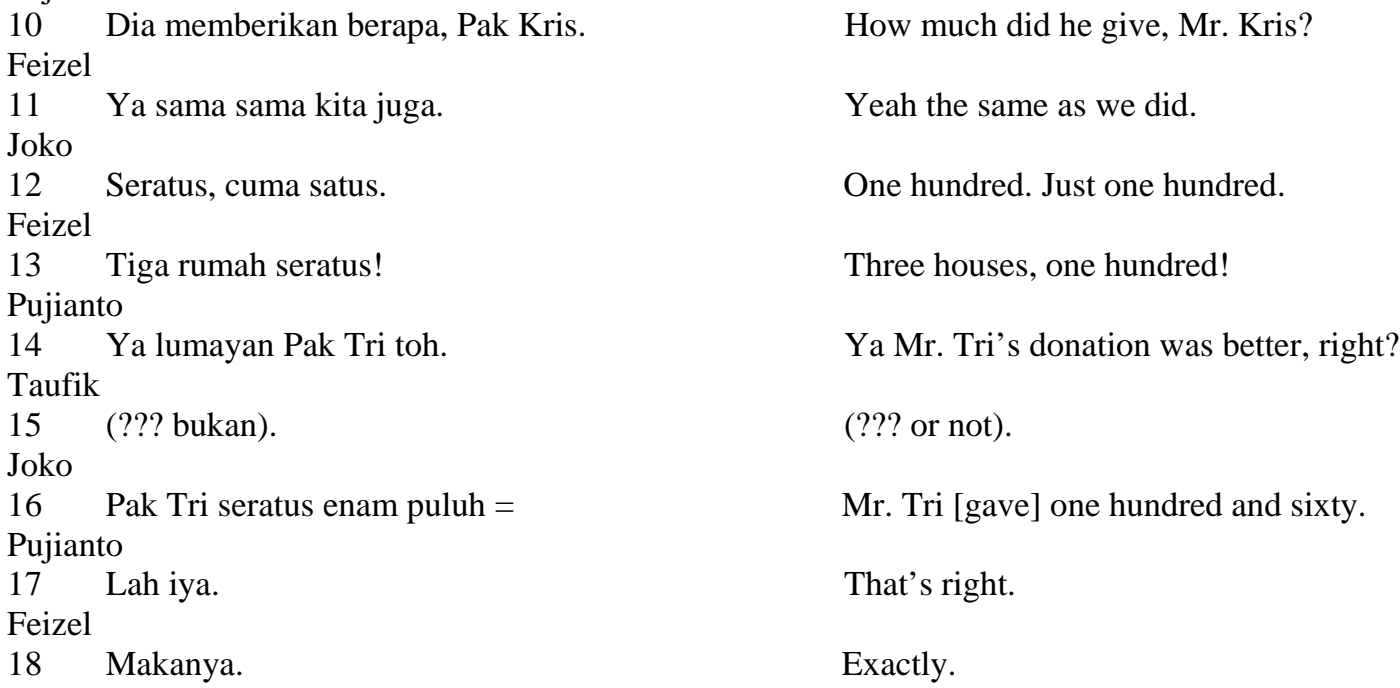

In the above conversation we can again see links with the talk in the previous meeting. In particular, we see here that on line 10 Pujianto asks the same question that he asked at the previous meeting (see the discussion preceding Extract 3) even though he knows the answer. The answers that he gets help to move what otherwise would have been an innocent question into the realm of gossip, further helping to stigmatise Kris. As with Extract 1, in this type of talk it is difficult to pin responsibility for the content of the talk on any participant in particular. Just as importantly, this talk revives the discussion started in the December meeting concerning Kris's contribution and generosity. Indeed, we can see these links through the representation of Kris's contribution as 'just one hundred' (line 12) and its comparison with Tri's contribution (lines 14-17). In addition, we can also see that Feizel hints at a difference in financial ability between those present at the meeting and Kris (lines 11 and 13). In doing so, this talk also helps to further solidify categories of wealthy and ordinary folk.

As with the conversation at the previous meeting, over the course of time additional participants contribute to this discussion (primarily Pujianto with a contribution from Taufik). Again this helps to make it hard to assign responsibility for this talk to any person in particular. In the discussion that directly follows, the categories of wealthy and ordinary folk further solidify as they are contrasted with other ideologies emanating 
from Islam. In particular, Taufik points out that in Islamic terms Kris has not yet donated, while Feizel points out that Kris should not be seeking to make profits from the ward where he lives. Taufik now becomes more directly involved in talk about Kris, increasing the number of participants actively involved in discussing Kris to four of the nine present. At this stage such representations of Kris seem to still be somewhat neutral, but in the ensuing discussion the stigmatisation of Kris through the association of his behaviour with Chineseness is made explicit.

Extract 6: Kris is an uncaring Chinese business person

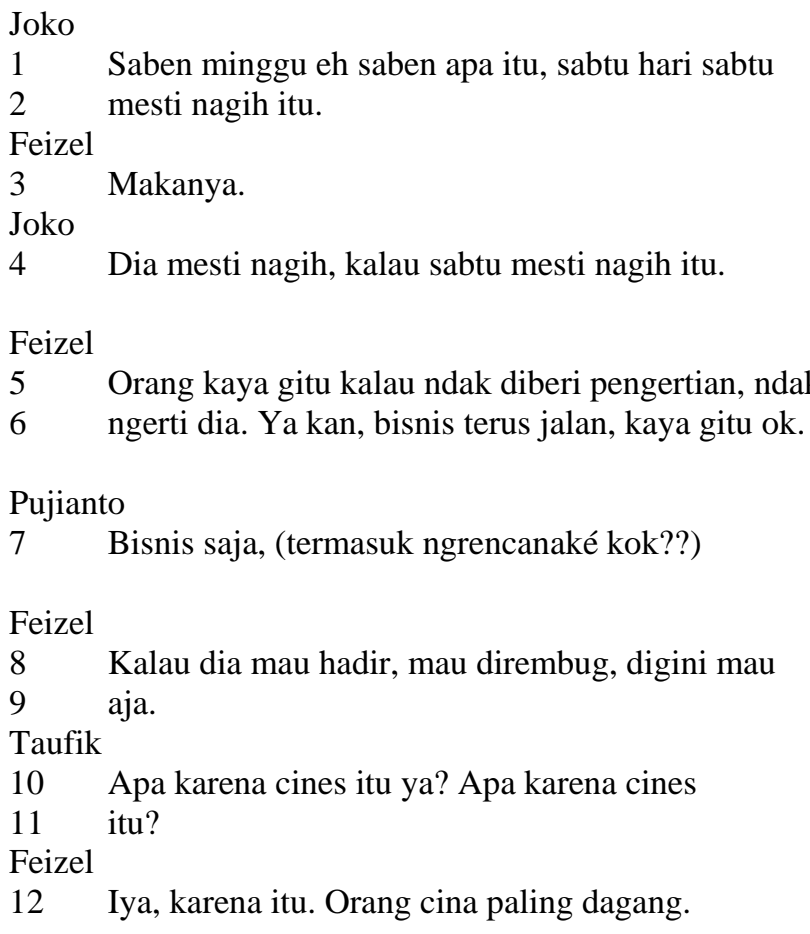

\author{
Each week, eh, each what is it Saturday, Saturday \\ [he] routinely comes to debt collect. \\ Exactly [my point]. \\ He always debt collects on Saturday, he always \\ debt collects.
People like that, if they are not told then they just don't understand, right? All [they] know is business, it is like that.
Just business, (including planning??)

If he wanted to attend [meetings] and negotiate, that would be OK.

Is it because [he] is Chinese? Is it because he is Chinese?

Yes, because of that. All Chinese do is do business.

We can see that Feizel's earlier comment about not taking profits seems to lead to Joko's reminding those present that Kris never misses an opportunity to collect debts (see the discussion after Extract 4). We also see the stigmatisation of Kris as someone who is only interested in money and business and not the condition of his ward's finances (lines 5-9). More importantly, however, is the now explicit racialisation of Kris as Chinese (lines 10-12), where Taufik ponders whether such deviant or strange behaviour is due to Kris's Chineseness. Here all the non-desirable and non-normative behaviour in this ward (non-donor, non-attender of meetings, wealthy stingy folk, and so on) are linked to Kris as an exemplar of Chineseness via the use of two words, Cines and Cina 'Chinese' (lines 10-12). 
While the first use of the term cines might have been a result of Taufik not wishing to invoke the racist connotations associated with the term Cina, Feizel does interpret Taufik's Cines in that way. Taufik does not correct Feizel's interpretation in subsequent turns. As the discussion continues Kris's negative behaviour is also contrasted with that of others who exemplify what Feizel, Taufik and Joko think should be proper conduct. In particular, we hear about Sunardi, who lives in another nearby low-income ward (and who is incidentally a trader not of Chinese ancestry). Sunardi is presented as similar to those present at the meeting and as an ideal person who never debt-collects despite the very large debts owed to him and his subsequent low income. His generosity is contrasted with Kris's behaviour, who continues to be positioned as someone who collects debts every week without fail, despite his privileged economic circumstances. This conversation serves to solidify an emerging local model of personhood relating to wealthy, stingy, non-Muslim folk and those who are poor but generous and Muslim.

Without reproducing the rest of the discussion, which goes one for another three minutes, the stigmatisation of Kris continues and with it the further entwining of local circumstances and ideas about morality and normativity with wider circulating stereotypes. Multiple participants are involved in the conversation, and Feizel threatens to engage in verbal conflict with Kris the next time they meet. Feizel justifies such a confrontation because of Kris's Chineseness rather than because of the non-normative behaviours that have, over time, resulted in a direct equation between Kris and the widely circulating negative stereotype of Chinese-Indonesians. In this sense, Kris as a local person has now been stigmatised to the extent that he now represents another example of an undesirable stereotypical Chinese-Indonesian persona.

\section{Conclusion}

Stories and gossip are a common part of social life in most parts of the world and they are one of the key communicative modes by which others are stigmatised. Both genres function to remind others about what is and is not acceptable behaviour in a particular setting, while also functioning as a means of trying to change another's behaviour. In this essay I have focused on the former function, although in the final part of this conclusion I comment on the latter function. Stories and gossip do not operate in a vacuum and to pull off the communicative work that these genres are famous for, stories and gossip rely on both local information and more widely circulating stereotypes. The 
formation of such stereotypes is an outcome of repetition of signs of personhood (including language use, social practices, and social space) in one-to-many participation frameworks, such as school classrooms, over a long period of time in multiple settings. In the case of the ward discussed in this essay, the key stereotypes are those relating to Chineseness that have their genesis in Dutch colonial policies and practices.

In looking at how stereotypes of Chineseness are used in neighbourhood talk in a middle income neighbourhood of Indonesia, I have analysed the stigmatisation of a ward member, Kris. My particular focus was on the discussion that occurred in two ward meetings in December 1996 and January 1997, which coincided with a number of important local and national events that helped to enable the categorisation of Kris as a deviant who was just like all other stereotypical Chinese in Indonesia. Given that stigmatisation is a process that unfolds across communicative events, responsibility for it is hard to direct at any individual ward member. Just as importantly, it seems that stigmatisation is often an unintended outcome of the intersection of talk across a number of temporally and spatially separated communicative events and social, economic, and political events at both the local and national levels. Moreover gossip also functions to change behaviours and social relations. In the case reported here, Kris got the message either from a neighbour present at ward meetings or perhaps via his wife, who was a regular attender of the parallel women's ward meetings held each month. Whatever the case, he regularly attended meetings from then on, donated more, and hosted a ward meeting, as all 'good' neighbours are expected to do.

\section{Reference List}

Agha, A. 2007, Language and Social Relations. Cambridge University Press, Cambridge.

Bakhtin, M. 1981, The Dialogic Imagination: Four Essays. trans. C. Emerson \& M. Holquist. University of Texas Press, Austin.

Bauman, R. 2004, A World of Others’ Words:Cross-cultural Perspectives on Intertextuality. Blackwell Publishers, Malden, MA.

Bauman, R., \& Briggs, C. 1990, 'Poetics and Performance as Critical Perspectives on Language and Social Life,’ Annual Review of Anthropology, vol. 19: 59-88.

Besnier, N. 2009, Gossip and the Everyday Production of Politics. University of Hawai'i Press, Honolulu.

Bourdieu, P. 1991, Language and Symbolic Power. Polity Press in association with Basil Blackwell, Cambridge.

Chua, C. 2004, 'Defining Indonesian Chineseness under the New Order,' Journal of Contemporary Asia, vol. 34, no. 4: 465-479.

Coppel, C. 1983, Indonesian Chinese in Crisis. Oxford University Press, Oxford.

Errington, J. 1998, Shifting Languages: Interaction and Identity in Javanese Indonesia. Cambridge University Press, Cambridge. 
2000, 'Indonesian(s) Authority,' in Regimes of Language: Ideologies, Polities, and Identities (Advanced Seminar Series), (ed.) P. V. Kroskrity. School of American Research, Santa Fe, NM: 205-227 2001, 'Colonial Linguistics,' Annual Review of Anthropology, vol. 30: 19-39.

Foucault, M. 1978, The History of Sexuality (Volume 1: An Introduction), trans. R. Hurley. Pantheon Books, New York.

Georgakopoulou, A. 2007, Small Stories, Interaction and Identities. John Benjamins Publishing Company, Amsterdam.

Goebel, Z. 2010, Language, Migration and Identity: Neighborhood Talk in Indonesia. Cambridge University Press, Cambridge.

Goffman, E. 1967, Interaction Ritual: Essays on Face-to-Face Behaviour. Anchor, New York.

Hymes, D. 1974, Foundations in Sociolinguistics: An Ethnographic Approach. University of Pennsylvania Press, Philadelphia.

Inoue, M. 2006, Vicarious Language: Gender and Linguistic Modernity in Japan. University of California Press, Berkeley.

Irvine, J. 2001, “'Style” as Distinctiveness: the Culture and Ideology of Linguistic Differentiation,' in Style and Sociolinguistic Variation, (eds) P. Eckert \& J. Rickford. Cambridge University Press, Cambridge: 21-43.

Kitley, P. 2000, Television, Nation, and Culture in Indonesia. Ohio University Press, Athens.

Labov, W., \& Waletzky, J. 1967, 'Narrative Analysis,' in Essays on the Verbal and Visual Arts, (ed) J. Helm. University of Washington Press, Seattle, WA: 12-44.

Ochs, E., \& Capps, L. 2001, Living Narrative. Harvard University Press, Cambridge.

Peirce, C. S. 1931-1958, The Collected Papers of Charles Sanders Peirce. Harvard University Press, Cambridge, MA.

Philips, S. U. 1983, The Invisible Culture: Communication in Classroom and Community on the Warm Springs Indian Reservation. Longman, New York.

Purdey, J. 2006, Anti-Chinese violence in Indonesia, 1996-1999. National University of Singapore Press, Singapore.

Sacks, H. 1986 [1972], 'On the Analyzability of Stories by Children,' in Directions in Sociolinguistics: The Ethnography of Communication, (eds) J. J. Gumperz \& D. Hymes. Blackwell, Oxford: 325345.

Sen, K., \& Hill, D. T. 2000, Media, Culture and Politics in Indonesia. Oxford University Press, Oxford. Stewart, P. J., \& Strathern, A. 2004, Witchcraft, Sorcery, Rumors, and Gossip. Cambridge University Press, Cambridge.

Vickers, A. 2005, A History of Modern Indonesia. Cambridge University Press, Cambridge.

Wortham, S. 2006, Learning Identity: The Joint Emergence of Social Identification and Academic Learning. Cambridge University Press, Cambridge. 